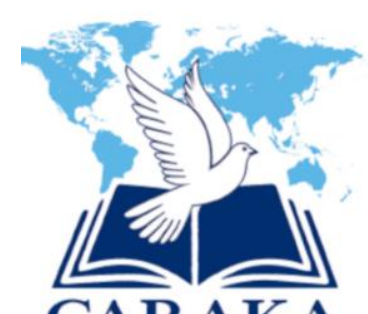

\begin{tabular}{|l|l|l|}
\hline Diserahkan: 15 Januari 2021 & Diterima: 14 Oktober 2021 & Diterbitkan: 2 November 2021 \\
\hline
\end{tabular}

\title{
Sikap Etis Kristen Terhadap Praktek Mengubah Lirik Lagu Dalam Nyanyian Sekuler Menjadi Nyanyian Rohani Kristen Di Dalam Gereja
}

\author{
Sinta Kumala Sari \\ Sekolah Tinggi Teologi Berea \\ sintaaliyanto85@gmail.com
}

\begin{abstract}
Christianity cannot be separated from the aspect of singing or praising God. But not just singing songs because in Christianity there are songs that are categorized as spiritual songs or congregational songs. However, today there are some Christians who deliberately "change the lyrics of a secular song into a Christian hymn." Even some of the songs that have been changed are sung in the church. Previous research on congregational singing in general still focuses on the meaning and importance of Christian hymns in worship. The purpose of this study was to understand how the ethical attitude towards the practice of changing song lyrics in secular songs into Christian hymns in the church. This study uses a qualitative approach methodology. The analysis used is interactive analysis which includes: First, data collection. Second, data presentation. Third, data reduction and Fourth, drawing conclusions. The results of the study found that First, it is better if the parties, either individually or in groups, ask permission from the copyright owner in advance if their work is to be modified. Second, secular songs whose song lyrics are converted into spiritual song lyrics are better not sung in church, let alone in worship songs.
\end{abstract}

Keywords: Christian Ethical Attitude; changing song lyrics; Christian hymn

\begin{abstract}
Abstrak
Kekristenan memang tidak bisa dilepaskan dari aspek menyanyi atau memuji Allah. Namun bukan sembarang menyanyikan lagu karena dalam Kekristenan terdapat lagu-lagu yang dikategorikan sebagai lagu Rohani atau nyanyian jemaat. Meskipun demikian, zaman sekarang ada sebagian orang Kristen yang dengan sengaja "mengubah lirik lagu dalam nyanyian sekuler menjadi nyanyian rohani Kristen." Bahkan lagu-lagu yang telah diubah tersebut ada beberapa yang dinyanyikan di dalam gereja. Penelitian sebelumnya mengenai nyanyian jemaat pada umumnya masih berfokus kepada makna dan arti penting nyanyian rohani Kristen dalam ibadah. Tujuan penelitian ini adalah untuk memahami bagaimana Sikap Etis Terhadap Praktek Mengubah Lirik Lagu Dalam Nyanyian Sekuler Menjadi Nyanyian Rohani Kristen Di Dalam Gereja. Penelitian ini menggunakan metodologi pendekatan kualitatif. Analisis yang digunakan adalah analisis interaktif yang mencakup: Pertama, pengumpulan data. Kedua, penyajian data. Ketiga, reduksi data dan Keempat, penarikan kesimpulan. Hasil penelitian menemukan bahwa Pertama, adalah lebih baik jika pihak-pihak baik secara pribadi atau kelompok meminta izin terlebih dahulu kepada pemiliki hak cipta jika hasil karyanya akan
\end{abstract}


dimodifikasi. Kedua, nyanyian sekuler yang lirik lagunya diubah menjadi lirik lagu rohani lebih baik tidak dinyanyikan di dalam gereja apalagi dalam nyanyian ibadah.

Kata kunci: Sikap Etis Kristen; Mengubah lirik lagu; Nyanyian rohani Kristen

\section{PENDAHULUAN}

Kekristenan tidak bisa dilepaskan dari aspek menyanyi atau memuji Allah. Namun bukan sembarang menyanyikan lagu karena dalam Kekristenan terdapat lagu-lagu yang dikategorikan sebagai lagu rohani atau nyanyian jemaat. Meskipun nyanyian jemaat merupakan bagian yang integral dalam ibadah Kristen yang mana melaluinya iman Kristen diekspresikan, namun pada era digital sekarang ini banyak dijumpai "nyanyian sekuler" yang lirik dan lagunya diubah menjadi rohani Kristen. Misalnya lagu "Hai Tayo"2 versi rohani, "Goyang Maumere"3 versi rohani, "Karna Ku Selow"4 versi rohani, "Meraih Bintang"5 versi rohani, "Sayur Kol"6 versi rohani, "Syantik"7 versi rohani, "Karena Su Sayang" versi rohani, dll. Versi rohani di sini berarti nyanyian-nyanyian sekuler tersebut diubah lirik dan lagunya menjadi lirik bernuasa iman Kristen. Bahkan lagu-lagu yang telah diubah tersebut ada beberapa yang dinyanyikan di dalam gereja. Beberapa contoh perubahan terlihat dalam tabel berikut ini:

${ }^{1}$ Menurut Kamus Besar Bahasa Indonesia, sekularisme adalah suatu pandangan dalam hidup atau dalam satu masalah yang berprinsip bahwa agama atau hal-hal yang bernuansa agama tidak boleh masuk ke dalam pemerintahan, atau pertimbangan-pertimbangan keagamaan harus dijauhkan darinya. https://andabertanyaateismenjawab.wordpress.com/2013/08/01/apa-sebenarnya-sekuler-itu-2/. Diakses tanggal 17 jam 12.10. Nyanyian sekuler dimaksud dalam tulisan ini adalah nyanyian yang tidak mengandung unsur iman Kristen.

${ }^{2}$ Hai Tayo versi asli https://www.youtube.com/watch?v=ThM0EdT1ByU Hey Tayo versi rohani https://www.youtube.com/watch?v=Z-UvDURdems

${ }^{3}$ Goyang Maumere versi asli https://www.youtube.com/watch?v=OP6mejYF4Tg, Versi rohani https://www.youtube.com/watch?v=HjlztOvV5AM

${ }^{4}$ Karna Ku Selow versi asli https://www.youtube.com/watch?v=6ZFdbaU8JPw, versi rohani https://www.youtube.com/watch?v=H0uI7dKCYYs

${ }^{5}$ Meraih Bintang versi asli https://www.youtube.com/watch?v=1ak17RxcqBQ, versi rohani https://www.youtube.com/watch?v=FVBYF0ae3wg

${ }^{6}$ Sayur Kol versi asli https://www.youtube.com/watch?v=Zhpx5qqMIVc, versi rohani https://www.youtube.com/watch?v=kSnnr1I9M_U

${ }^{7}$ Syantik versi asli https://www.youtube.com/watch?v=Tet6 BlStEM, versi rohani https://www.youtube.com/watch?v=NPnVTF5blMg

${ }^{8}$ Karna Su Sayang versi asli https://www.youtube.com/watch?v=7xLR7r 0Ktc, Versi rohani https://www.youtube.com/watch?v=FsDX5QmO9rc 
Tabel 1

Versi Asli Versus Versi Rohani

\begin{tabular}{|c|c|}
\hline \multicolumn{2}{|c|}{ Judul Lagu: Karna Ku Selow } \\
\hline Versi Asli ${ }^{9}$ & Versi Rohani Kristen \\
\hline $\begin{array}{l}\text { Sudah biasa diriku ditinggalkan } \\
\text { Diacuhkan dan dicampakkan } \\
\text { Oleh orang yang ku cinta } \\
\text { Menyakitkan tapi tak ku rasakanKu pasrahkan } \\
\text { semua pada Tuhan } \\
\text { Yang telah mengatur semua } \\
\text { Jalanku dan juga jodohku } \\
\text { Dimanapun kapanpun itu } \\
\text { Karena ku selow, sungguh selow } \\
\text { Sangat selow, tetap selowSantai, santai, } \\
\text { jodoh gak akan kemana } \\
\text { Karena ku selow, sungguh selow } \\
\text { Sangat selow, tetap selowSantai, santai, } \\
\text { ku yakin tuhan berikan gacoan }\end{array}$ & $\begin{array}{l}\text { Tuhan Yesus selalu bersamaku untuk } \\
\text { skarang dan slamanya } \\
\text { Engkau tempat harapanku } \\
\text { Hanya Kaulah yang selalu kupuja dan ku } \\
\text { sembah selamanya sekarang dan hari } \\
\text { esok di saat ku takut Dia slalu } \\
\text { menolongku kapan pun itu } \\
\text { Karena ku selow, sungguh selow enggak } \\
\text { takut, nggak cemas, santai Tuhan selalu } \\
\text { menyertai } \\
\text { Karena ku selow, sungguh selow enggak } \\
\text { takut, nggak cemas, santai ku yakin } \\
\text { Tuhan berikan kekuatan }\end{array}$ \\
\hline \multicolumn{2}{|c|}{ Judul Lagu : Sayur Kol } \\
\hline $\begin{array}{l}\text { Waktu abang pergi ke Siborong-borong } \\
\text { Datang hujan yang amat deras lah } \\
\text { Terkejut abang terheran - heran } \\
\text { Sebab abang belum pernah kesana } \\
\text { Bridge: } \\
\text { Untung datang namboru panjaitan } \\
\text { Martarombo kami di jalan } \\
\text { Diajaknya aku ke rumah dia } \\
\text { Makan daging anjing dengan sayur kol } \\
\text { Reff: } \\
\text { Sayur Kol.. Sayur Kol.. } \\
\text { Makan daging anjing dengan sayur kol } \\
\text { Sayur Kol.. Sayur Kol.. } \\
\text { Makan daging anjing dengan sayur kol } \\
\text { Bridge: } \\
\text { Untung datang namboru panjaitan } \\
\text { Martarombo kami di jalan } \\
\text { Diajaknya aku ke rumah dia } \\
\text { Makan daging anjing dengan sayur kol } \\
\text { Reff: } \\
\text { Sayur Kol.. Sayur Kol } \\
\text { Makan daging anjing dengan sayur kol } \\
\text { Sayur Kol.. Sayur Kol.. } \\
\text { Makan daging anjing dengan sayur kol }\end{array}$ & $\begin{array}{l}\text { Waktu adik ajak kamu kegereja } \\
\text { Kamu selalu punya alasan-lah } \\
\text { Ketika sudah mau natal dan paskah } \\
\text { Kamu baru mau ke gereja } \\
\text { Bridge: } \\
\text { Untung sekarang di paroki lagi ada } \\
\text { pengakuan dosa dimana-mana } \\
\text { Adik ajak kamu tobat untuk sambut } \\
\text { Yesus dengan Bahagia } \\
\text { Onamas...Onamas... } \\
\text { Adik ajak kamu kegeraja } \\
\text { Waktu adik ajak kamu kegereja } \\
\text { Kamu selalu punya alasan-lah } \\
\text { Ketika sudah mau natal dan paskah } \\
\text { Kamu baru mau ke gereja } \\
\text { Bridge: } \\
\text { Untung sekarang di paroki lagi ada } \\
\text { pengakuan dosa dimana-mana } \\
\text { Adik ajak kamu tobat untuk sambut } \\
\text { Yesus dengan Bahagia } \\
\text { Onamas...Onamas... } \\
\text { Adik ajak kamu kegeraja }\end{array}$ \\
\hline
\end{tabular}

${ }^{9}$ Via Vallen pada Selasa 4 Desember 2018 merilis video klip lagu terbarunya berjudul Selow. Lagu ini menceritakan tentang seseorang yang santai tak terlalu memikirkan jodoh lantaran yakin Tuhan sudah mengatur jodohnya. Begitu dirilis, lagu ini langsung menarik perhatian masyarakat. Terbukti, dua hari setelah diluncurkan, single Via Vallen ini menduduki peringkat 3 trending YouTube. Video itu sudah ditonton lebih dari 1,4 juta kali. https://www.tabloidbintang.com/lirik-lagu/read/795/lirik-lagu-selow-via-vallen. Diakses tanggal 17 Agustus 2019 jam 17.00 Wib.

256 | Copyright $\odot$ 2021, CARAKA, ISSN 2722-1407 (Cetak), 2722-1393 (Online) 
Hasil penelusuran melalui Forum Kristen. com tema "Lagu Sekuler Dilantunkan Dalam Gereja" menjadi salah satu topik dalam kategori very hot topik yang telah dibaca 4921 kali dengan 52 argumentasi dari 52 denominasi gereja. Namun sampai saat ini belum ada jawaban yang pasti mengenai etis atau tidaknya tindakan tersebut. ${ }^{10}$ Khususnya dalam perspektif etika Kristen. Penelitian sebelumnya mengenai nyanyian jemaat pada umumnya masih berfokus kepada makna dan arti penting nyanyian rohani Kristen dalam ibadah. Misalnya penelitian dari Rohani Siahaan dengan judul "Memuji Dengan Nyanyian Dalam Ibadah Jemaat" menegaskan bahwa memuji dengan nyanyian rupanya perlu dimaknai secara benar dan tepat karena dalam ibadah, nyanyian dan pujian berperan membawa kita memasuki hadirat Tuhan. ${ }^{11}$ Penelitian Nindyo Sasongko dengan judul Mengenal Nyanyian Gereja Dan Tempatnya Dalam Liturgi menemukan bahwa jemaat perlu mengambil sikap yang bertanggung jawab dalam memilih nyanyian gereja. Jangkauan tulisan ini yaitu pada teologi nyanyian jemaat, tempat nyanyian jemaat dalam liturgi gereja serta kandungan teologis sebuah himne. ${ }^{12}$ Dengan demikian belum ada penelitian tentang bagaimana fenomena tersebut disikapi berdasarkan etika Kristen? Berdasarkan realitas yang sedang marak terjadi yaitu mengubah lirik lagu nyanyian sekuler menjadi nyanyian Rohani maka tulisan ini mengambil judul: Sikap Etis Kristen Terhadap Praktek Mengubah Lirik Lagu Dalam Nyanyian Sekuler Menjadi Nyanyian Rohani Kristen Di Dalam Gereja.

\section{METODE PENELITIAN}

Penelitian ini menggunakan metodologi pendekatan kualitatif. ${ }^{13}$ Sumber data didapatkan dari studi Alkitab dan literatur yang terdiri dari buku-buku, internet, artikel, serta data tertulis lain yang berkaitan dengan penelitian ini. ${ }^{14}$ Analisis yang digunakan adalah analisis interaktif yang mencakup: Pertama, pengumpulan data. Kedua, penyajian data. Ketiga, reduksi data dan Keempat, penarikan kesimpulan. ${ }^{15}$ Langkah kerja yang dilakukan: pertama adalah melihat Perbedaan Antara "Cover Lagu” Dan "Merubah Lirik Lagu” khususnya lirik lagu sekuler menjadi rohani Kristen. Kedua adalah pemahaman mendasar tentang etika Kristen. ketiga menjelaskan Sikap etis Kristen terhadap praktek mengubah lirik lagu dalam

${ }^{10} \mathrm{Http}: / /$ forumkristen.com/index.php?topic=54775.0. Diakses tanggal 20 Agustus 2019 jam 10:12 Wib.

${ }^{11}$ Rohani Siahaan, Memuji Dengan Nyanyian Dalam Ibadah Jemaat. (Jurnal Jafray Sekolah Tinggi Theologia Jaffray vol.5, nol. 2007).

${ }_{12}$ Nindyo Sasongko, Mengenal Nyanyian Gereja Dan Tempatnya Dalam Liturgi (jurnal Veritas 8/2 Oktober 2007), 205-229.

${ }^{13}$ Stevri Indra Lumintang dan Danik Astuti Lumintang, Theologia Penelitian dan Penelitian Theologis Science-Ascience serta Metodologinya, (Jakarta: Geneva Insani Indonesia, 2016), 23.

${ }^{14}$ Andreas S.Subagyo, Pengantar Riset Kuantitatif dan Kualitatif, (Bandung: Yayasan Kalam Hidup, 2004), 161-162.

${ }^{15}$ M. B Miles \& Huberman, A. M. Qualitative Data Analysis: A Sourcebook of New (California. Sage Publication Inc, 1984), 23. 
nyanyian sekuler menjadi nyanyian rohani Kristen di dalam gereja. Keempat adalah penarikan kesimpulan.

\section{HASIL DAN PEMBAHASAN}

\section{Perbedaan Antara "Cover Lagu" Dan "Merubah Lirik Lagu"}

Cover song adalah menyanyikan kembali lagu yang pernah dirilis secara komersial sebelumnya. ${ }^{16}$ Menurut Triindaryani, Cover lagu adalah menyanyikan ulang lagu dari artis atau penyanyi terkenal dengan versi suara kita sendiri. Atau kita menyanyikan ulang lagu diiringi alat musik seperti gitar, piano atau alat musik lain sesuai gaya kita tanpa mengubah lirik serta lagu aslinya. ${ }^{17}$ Atau dengan kata lain cover itu seperti membawakan sebuah karya orang lain tapi tidak mengakui bahwa karya itu milik kita. Berbeda dengan plagiat yang mencontek/menjiplak baik itu keseluruhan maupun sebagian dari karya orang lain dan mengakui karya tersebut sebagai karyanya sendiri. ${ }^{18}$ Bahkan seringkali cover song malah dijadikan sebagai bentuk tribut atau penghargaan terhadap sebuah lagu atau karya musisi yang memiliki keistimewaan tertentu, misalnya dari segi lirik, prestasi lagu tersebut, atau sepak terjang musisi asli dalam dunia musik. ${ }^{19}$ "Mengcover sebuah lagu kadang membuat lagu tersebut menjadi lebih bagus atau malah menjadi jelek." ${ }^{20}$ Berdasarkan pengertian tersebut diatas, maka perlu digaris bawahi disini adalah tindakan mengcover lagu tidak mengijinkan merubah lirik lagu.

Lirik lagu merupakan susunan/rangkaian kata yang bernada, lirik lagu memang tidak semudah menyusun karangan, namun dapat diperoleh dari berbagai inspirasi. Inspirasi itu sendiri dapat diperoleh dari pengalaman dalam kehidupan sehari-hari. ${ }^{21}$ Menurut Tri Juniarti lirik lagu mencakup beberapa aspek yaitu: Lirik lagu merupakan ekspresi seseorang tentang suatu hal yang sudah dilihat, didengar maupun dialaminya. Dalam mengekspresikan pengalamanya, pencipta lagu melakukan permainan kata-kata dan bahasa untuk menciptakan daya Tarik dan kekhasan terhadap lirik atu syairnya tersebut. lirik lagu juga terbentuk dari bahasa yang dihasilkan dari komunikasi antara pencipta lagu dengan masyarakat penikmat

${ }^{16}$ http://one-olyvia.blogspot.com/2012/01/apa-itu-cover-song.html. Diakses tanggal 20 Agustus 2019 jam 11: 33 Wib.

${ }^{17}$ Tri indaryani, Cover Lagu Artis Nggak Boleh Asal Lho! Cek Aturannya Yuk!. https://batam.tribunnews.com/2018/01/25/cover-lagi-artis-nggak-boleh-asal-lho-cek-aturannya-yuk. Diakses tanggal 20 Agustus 2019 jam 11: 33 Wib.

${ }^{18} \mathrm{Https}$ //www.facebook.com/notes/rasyadan-alghazian-grantiarno/mudah2an-ini-bisa-membantumenjelaskan-perbedaan-cover-dengan-plagiat-/396712254829/

${ }^{19} \mathrm{Https} / / /$ any.web.id/arti-cover-song.info

${ }^{20} \mathrm{Http}$ ://one-olyvia.blogspot.com/2012/01/apa-itu-cover-song.html

${ }^{21}$ Https://www.gurupendidikan.co.id/8-pengertian-lirik-lagu-menurut-para-ahli-lengkap/ 
lagu. Lirik lagu merupakan ekspresi seseorang dari dalam batinya tentang sesuatu hal baik yang sudah dilihat, didengar maupun dialami. ${ }^{22}$

Oleh sebab itu, dalam menggunakan lirik seorang penyair atau pencipta lagu harus benar-benar pandai mengolah kata." ${ }^{23}$ Berdasarkan kedua pengertian inilah maka tindakan mengubah nyanyian sekuler menjadi nyanyian rohani Kristen dalam beberapa contoh diatas lebih tepat dikategorikan sebagai tindakan "mengubah lirik lagu" bukan "cover lagu." Oleh sebab itu praktek merubah lirik lagu sekuler menjadi rohani yang sering dijumpai di media sosial misalkan Youtube tidak tepat jika dipahami sebagai praktek cover lagu bahkan kemudian si pembuat tersebut menyebutnya juga demikian. Penelitian ini lebih fokus melihat fakta mengenai praktek mengubah lirik lagu sekuler menjadi rohani Kristen yang kemudian dinyanyikan di dalam Gereja.

\section{Pemahaman Tentang Etika Kristen}

Menurut Magnis Etika adalah ilmu yang mencari orientasi, yaitu orientasi bagi usaha manusia untuk menjawab suatu pertanyaan yang amat fundamental: bagaimana saya harus hidup dan bertindak ${ }^{24}$ Etika hanya dapat disebut etika, apabila ia tidak hanya bersifat universal, tetapi juga Kontekstual. ${ }^{25}$ Etika hanya memberikan kepada kita pertimbanganpertimbangan pokok sebagai bahan dalam mengambil keputusan. Oleh karena itu, etika tidak menyajikan keputusan-keputusan. Etika memberikan pertimbangan untuk mengambil keputusan. ${ }^{26}$ Bertens mengusulkan metode dalam etika terapan yang mencakup: pertama, Sikap awal. Dalam usaha membentuk suatu pandangan beralasan tentang masalah etis apapun, kita tidak pernah bertolak dari titik nol. Selalu ada suatu sikap awal. Kita mulai dengan mengambil suatu sikap tertetu terhadap masalah bersangkutan. ${ }^{27}$ Kedua, Informasi. Melalui informasi kita dapat mengetahui bagaimana keadaan obyektif itu, karena bisa saja terjadi sikap awal yang pro dan kontra yang sebenarnya masih sangat emosional atau sekurang-kurangnya dikuasai oleh faktor subyektif yang tidak sesuai dengan kenyataan obyektif. ${ }^{28}$ Ketiga, Norma-norma Moral. Norma-norma moral yang relevan disini merupakan topik atau bisang yang bersangkutan yang sudah diterima dalam masyarakat. Tidak bisa disangkal, penerapan norma-norma moral ini merupakan unsur terpenting dalam metode etika

\footnotetext{
${ }^{22}$ Tri Junia Kristianti. Analisis Gaya Bahasa: Bab II Landasan Teori. http://repository.ump.ac.id/5492/3/Tri\%20Junia\%20Kristiyanti_BAB\%20II.pdf

${ }^{23}$ Ibid.,

${ }^{24}$ Frans Magnis Suseno, Etika Dasar: Masalah-Masalah Pokok Filsafat Moral (Yogyakarta: Penerbi Kanisius, 1987), 13.

${ }^{25}$ Phil. Eka Darmaputera, Etika Sederhana Untuk Semua: Perkenalan Pertama ( Jakarta: BPK Gunung Mulia, 2002), 95.

26 Ibid,.

${ }^{27}$ K. Bertens, Etika: Seri Filsafat Atma Jaya: 15 (Jakarta: PT Gramedia Pustaka Utama, Jakarta, 2004), 295.

${ }^{28}$ Ibid, 297. 
terapan. ${ }^{29}$ Keempat, Logika uraian yang diberikan dalam etika terapan harus bersifat logis. Logika dapat memperlihatkan bagaimana dalam suatu argumentasi tentang masalah perkaitan kesimpulan etis dengan premis-premisnya dan juga apakah penyimpulan itu tahan uji, jika diperiksa secara kritis menurut aturan-aturan logika. ${ }^{30}$

Secara sederhana apa yang membedakan etika Kristen dengan etika lainya? Dalam etika Kristen iman Kristiani dipakai untuk menjadi asumsi dasar dalam melakukan penilaian etis. ${ }^{31}$ Menurut Boersema Kitab Suci (Alkitab) adalah sumber utama untuk Etika Kristen. ${ }^{32}$ Mereka yang tidak menerima Alkitab sebagai Firman Tuhan seringkali mengatakan bahwa orang Kristen yang menerima Alkitab sebagai sumber Etika adalah orang yang biblisistis. Tuduhan itu tidak tepat bila pembaca Alkitab yang menerima wibawa Alkitab memperhatikan juga konteks setiap nas. Menurut Douma sebagaimana dikutip oleh Boersema bahwa dapat dibedakan antara empat penggunaan Alkitab: 1. Apabila digunakan secara langsung, Alkitab adalah seperti pemandu. Dalam keadaan konkrit terdapat petunjuk Alkitab yang konkrit. 2 . Alkitab adalah tetap seperti penjaga, yang tidak menunjuk jalan yang benar tetapi memberikan aba-aba untuk tidak ikut jalan yang salah. Dalam keadaan konkrit Alkitab memberikan peringatan untuk tidak melakukan sesuatu yang salah itu. 3. Alkitab digunakan juga sebagai penunjuk arah, yang dalam lalu lintas menunjuk tujuan kepada pengemudi-pengemudi. Sebab Alkitab memberikan faktor-faktor yang tetap, dan yang direktif bagi kita. 4. Di samping itu Alkitab memberikan banyak contoh, mis. dari Yesus Kristus sendiri: contoh-contoh seperti itu sering tidak mengajar kelakuan konkrit melainkan etos Kristen secara umum. ${ }^{33}$

Menurut Geisler ada beberapa karakteristik yang membedakan mengenai etika Kristen dengan etika yang lain. Diantaranya: pertama, Etika Kristen Berdasarkan Kehendak Allah.

Etika Kristen didasarkan pada kehendak Allah, dan Allah tidak pernah menghendaki apapun yang bertentangan dengan karakter moral-Nya yang tidak berubah. Misalnya Imamat: 11: 45; Matius 5: 48; Ibrani 6: 18; 1 Yohanes 4: 16; Matius 22: $39 .{ }^{34}$ Kedua, Etika Kristen Bersifat Mutlak. Karena karakter moral Allah tidak berubah (Maleakhi 3: 6; Yakobus 1: 17), maka kewajiban-kewajiban moral yang berasal dari natur-Nya itu bersifat mutlak. Maksudnya adalah, kewajiban-kewajiban tersebut selalu mengikat setiap orang dimana-mana. ${ }^{35}$ Ketiga, Etika Kristen Berdasarkan Wahyu Allah. Etika Kristen didasarkan pada perintah-perintah Allah, Wahyu yang bersifat umum (Roma 1: 19-20; 2: 12-15) dan khusus (Roma 2: 18; 3: 2). Allah telah menyatakan diri-Nya baik melalui alam (Mazmur 19: 1-6) dan di dalam Kitab Suci (Mazmur 19: 7-14). Wahyu umum berisikan perintah Allah bagi semua orang. Wahyu khusus mendeklarasikan

${ }^{29}$ Ibid, 299.

${ }^{30}$ Ibid, 301.

${ }^{31}$ Ibid, 97.

32 Jan Boersema, Etika Kristen. STT SETIA, mei 2014 https://www.janboersema.com/attachments /article/30/Etika\%20Kristen,\%20STT\%20SETIA,\%20mei\%202014.pdf. Diakses tanggal 27 jam 11: 44 Wib.

${ }^{33}$ Ibid,.

${ }^{34}$ Norman L. Geisler, Etika Kristen: Pilihan dan Isu (Malang: Seminari Alkitab Asia Tengara Malang, 2000), 24

${ }^{35}$ Ibid,. 
kehendak-Nya untuk orang-orang percaya. tetapi di dalam kedua hal tersebut, dasar dari tanggung jawab etis manusia adalah wahyu ilahi. ${ }^{36}$ Keempat, Etika Kristen Bersifat Menentukan. Etika berkaitan dengan apa yang seharusnya dilakukan, bukan dengan apa yang sebenarnya sedang terjadi. Orang-orang Kristen tidak menemukan kewajiban-kewajiban etis mereka di dalam standar orang-orang Kristen tetapi di dalam standar bagi orang-orang Kristen di Alkitab. ${ }^{37}$ Kelima, Etika Kristen Itu Dentologis. Etika Kristen itu deontologis (berpusat pada tujuan): peraturan menentukan hasil, dasar tindakan, peraturan itu baik tanpa menghiraukan hasil dan hasil selalu diperhitungkan nerdasar peraturan. ${ }^{38}$

\section{Sikap Etis Kristen Terhadap Praktek Mengubah Lirik Lagu Dalam Nyanyian Sekuler Menjadi Nyanyian Rohani Kristen Di Dalam Gereja}

\section{Praktek “Mengubah Lirik Lagu” Dalam Kaitan dengan Hukum Indonesia}

Dalam konteks Indonesia, beberapa kasus persoalan hukum yang muncul berkaitan dengan "praktek mengubah lirik lagu" lebih menjurus ke dalam persoalan-persoalan politik. Misalnya Fahmi Sahab yang melaporkan Tim sukses Ahok-Djarot kepada pihak berwajib karena melanggar hak cipta dengan kasus mengganti lirik lagu "kopi dangdut" secara total untuk berkampanye. ${ }^{39}$ Selain itu juga ada Rapper Marzuki Mohamad alias Kill The DJ merasa geram nada lagunya yang bertajuk Jogja Istimewa digunakan pendukung paslon presiden dan wakil presiden Prabowo Subianto-Sandiaga Uno. Pernyataan itu ia sampaikan lewat akun Twitter dan Instagram. ${ }^{40}$

Risa Amikrasi S.S., M.H. memberikan jawaban terhadap persoalan hukum memodifikasi lirik lagu untuk kampanye pemilu. Menurutnya hukum yang mengatur mengenai hal itu terdapat dalam Undang-Undang Nomor 28 Tahun 2014 tentang Hak Cipta (UUHC) - mengenai perlindungan Hak Cipta lagu sebagai Ciptaan berbentuk lagu dan/atau musik dengan atau tanpa teks. Jadi dalam suatu lagu sebenarnya ada beberapa Ciptaan yang terkandung di dalamnya sebagai suatu kesatuan. Bisa musiknya saja atau musik dengan teks. Pada suatu lagu yang musik dan teksnya diciptakan oleh orang yang sama dalam satu kesatuan yang utuh, maka setiap orang yang ingin mengubah teksnya wajib mendapatkan izin dari penciptanya. $^{41}$

\section{${ }^{36}$ Ibid, 25.}

${ }^{37}$ Ibid, 26.

${ }^{38}$ Ibid,

${ }^{39}$ Ferri Amiril Mukminin Mengubah Total Lirik Lagu Miliknya, Fahmi Sahab Sebut Tim Sukses AhokDjarot Melanggar Hak Cipta, https://jabar.tribunnews.com/2017/04/12/. Diakses pada tanggal 20 Agustus 2019 jam 19.00 Wib.

${ }^{40} \mathrm{Https}$ //www.cnnindonesia.com/hiburan/20190115105759-227-360889/kasus-jogja-istimewa-proprabowo-bisa-dibawa-ke-ranah-hukum. Diakses pada tanggal 20 Agustus 2019 jam 19.00 Wib. Lagu itu, kata Kill The DJ, ia ciptakan sendiri. Ia kemudian menyanyikannya bersama Jogja Hip Hop Foundation (@javahiphop). Ia pun merasa tidak pernah memberi izin kepada siapa pun untuk menggunakan lagu Jogja Istimewa itu sebagai alat kampanye.

${ }^{41}$ Risa Amikrasi, hukumnya memodifikasi lirik lagu untuk kampanye. https://www.hukumonline.com/klinik/detail/ulasan/lt5c8f438ae674d/hukumnya-memodifikasi-lirik-lagu-untuk- 
Senada dengan pandangan diatas, Deris Suhendar berdasarkan hasil penelitianya menyatakan bahwa lagu yang telah diubah liriknya tanpa izin dari pihak pencipta telah melanggar pasal 8 UUHC, serta dalam perubahan lirik lagu tersebut akan melanggar hak moral Pasal 5 UUHC. Bentuk tindakan hukum yang diberikan diantaranya penyelesaiyan sengketa dengan menempuh negosiasi, Pasal 95, Pasal 96 dan ketentuan pidana yang terdapat dalam Pasal 112 sampai dengan Pasal 119 UUHC. ${ }^{42}$

Berdasarkan pertimbangan dari sisi dan contoh hukum di Indonesia sebenarnya praktek mengubah lirik lagu sekuler menjadi lirik lagu rohani Kristen tidak menjadi masalah asalkan mendapatkan izin dari pemilik hak cipta. Banyaknya praktek demikian sepertinya tidak menimbulkan persoalan hukum meskipun pemilik hak cipta tidak mendapat izin terlebih dahulu karena pemilik hak cipta tidak merasa dirugikan. Jika pemilik hak cipta merasa dirugikan, kemudian menggugat dipengadilan maka akan menimbulkan persoalan hukum sehingga pihak pengganti lirik lagu bisa dikenakan pasal tentang Undang-Undang Hak cipta.

Proses perizinan terhadap pemilik hak cipta berdasarkan iman Kristen adalah nilai yang sangat mendasar. Memang dalam Alkitab tidak ada kasus yang secara spesifik membahas persoalan ini. Namun paling tidak beberapa teks Alkitab bisa menerangi praktek ini. Misalnya dalam sepuluh perintah Allah yang terdapat dalam Keluaran 20: 2-17 dan di Ulangan 5: 6-21 terutama dalam urutan yang ke 7 disana dikatakan "Jangan mencuri." Memang praktek merubah lirik lagu sekuler menjadi rohani bukanlah kategori mencuri dalam hukum Indonesia karena undang-undang pencurian ada tersendiri. Namun secara moral dan hati Nurani adalah lebih baik ijin terlebih dahulu kepada pemilik hak cipta ketika seseorang mau menganti lirik lagu sekuler menjadi rohani.

\section{Praktek “Mengubah Lirik Lagu” Dalam Kaitan Dengan Aspek Historis-Teologis}

Lirik lagu dalam sebuah nyanyian pada umumnya berasal dari pengalaman hidup sehari-hari. Catatan sejarah menunjukan bahwa lagu-lagu rohani Kristen lahir dari pengalaman-pengalaman iman Kristen yang real. Dalam buku berjudul "Kisah Nyata di Balik Lagu Pilihan" diungkapkan bahwa banyak nyanyian rohani yang lahir dari pengalaman pribadi pengarangnya. Banyak juga yang tercipta dari membaca ayat-ayat tertentu dalam Alkitab, dari mendengarkan khotbah atau kesaksian berdasarkan firman Tuhan." ${ }^{43}$ Senada dengan hal itu,

kampanye-pemilu. Diakses pada tanggal 20 Agustus 2019 jam 19.10 Wib.

${ }^{42}$ Aspek Hukum Perubahan Bahasa Terhadap Lirik Lagu Tanpa Izin Berdasarkan Undang-Undang Nomor 19 Tahun 2002 Tentang Hak Cipta Sekripsi Oleh: Deris Suhendar 110110080170 Program Kekhususan: Perdata Pembimbing: Dr. Muhamad Amirulloh, S.H., M.H. Sudaryat, S.H., M.H. Fakultas Hukum Universitas Padjajaran Bandung 2014

${ }^{43}$ Editor Andreas Sudarsono dan Dorean Widjana, Kisah Nyata di Balik Lagu Pilihan (Bandung: Lembaga 262 | Copyright@ 2021, CARAKA, ISSN 2722-1407 (Cetak), 2722-1393 (Online) 
Kenneth W. Osbeck dalam bukunya berjudul "Hymn Stories: The inspiring true stories behind 101 favorite hymns mengisahkan tentang pengalaman-pengalaman Kristen real yang melatarbelakangi lahirnya lirik lagu rohani Kristen." 44 Salah satu tokoh yang dibahas dalam buku tersebut adalah Marthin Luther dengan karyanya "A Mighty Fortress Is Our God" berdasarkan Mazmur 46. "This hymn became the battle cry of the people, a great source of strength an inspiration even for those who werw martyred for their convictions (nyanyian rohani ini menjadi seruan perang rakyat, sumber kekuatan yang hebat inspirasi bahkan bagi mereka yang mati syahid karena keyakinan mereka)". ${ }^{45}$

Catatan-catatan dalam Alkitab tentang nyanyian pujian didasarkan atas pengalaman real para tokoh dengan Allah dan kuasa-Nya. Misalnya Nyanyian Musa dalam Teks Keluaran 15 mengungkapkan bahwa Allah adalah "Pahlawan Perang atau The LORD is a warrior"

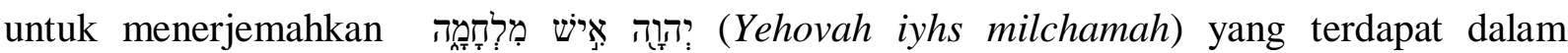
Keluaran 15: 3. "Nyanyian Musa didasarkan pada kuasa Allah yang memampukan dan dialami oleh Musa bangsa Israel menyeberangi laut Tebereu dan menaklukan Bangsa Mesir."46 Nyanyian Hana dalam 1 Samuel 2: 1-10 juga diasarkan atas pengalamanya dengan Allah. Doa Hana adalah kesaksian bagi anugerah Allah di dalam hidupnya. Hana tidak memiliki anak karena Tuhan telah menutup kandungannya $(1: 2,5)$. Hatinya disakiti oleh Penina, istri lain dari suaminya (1:6). Tetapi ketika Hana merendahkan diri di hadapan Tuhan, Dia menolongnya $(1: 10,27)$. Ketika dia menyerahkan anaknya kepada Tuhan sebagai penggenapan nazarnya, dia merayakan kebaikan Allah dengan nyanyian pujian ini $(1: 11,28)$. Di bagian tengah pujian ini terdapat kesaksian pribadinya: "Bahkan orang yang mandul melahirkan tujuh anak" (2:5). Angka tujuh di sini melambangkan kesempurnaan perannya sebagai seorang ibu. ${ }^{47}$

Nyanyian Hana dalam sepuluh ayat permulaan pasal ini merupakan doa ucapan syukurnya sewaktu ia menyerahkan putranya yang masih kecil. Menurut Holdcroft nyanyian doa tersebut merupakan perintis dari Nyanyian Pujian Maria (Lukas 1: 46-55). Hana lebih suka mengungkapkan terima kasih kepada Sang Pemberi, daripada membiarkan dirinya semata-mata memperhatikan karunia yang diperolehnya. Ungkapan "tanduk kekuatanku ditinggikan oleh Tuhan" merupakan cara Hana mengemukakan bahwa Allah telah

\footnotetext{
Literatur Baptis, 2005), 311.

${ }^{44}$ Kenneth W. Osbeck, 101 Hymns Stories: The inspiring true stories behind 101 favorite hymns (Michigan: Kregel Publications, 1982),.

45 Ibid, 13.

${ }^{46}$ Gary Edward Schnittjer, The Torah Story: An Apprenticeship On The Pentateuch (Malang: Gandum Mas, 2015), 233.

${ }^{47}$ Http://terangalkitab.net/2015/06/15/nyanyian-pujian-hana/. Diakses Tanggal 22 Agustus 2019 jam 9: 24. 263 | Copyright@ 2021, CARAKA, ISSN 2722-1407 (Cetak), 2722-1393 (Online)
} 
menghormatinya dan telah memberinya kekuatan, martabat dan kedudukan. Tetapi di atas semuanya. Ia bersukacita karena Allah sangat berarti bagi dirinya. ${ }^{48}$

Selain dari kedua contoh tersebut kitab Mazmur mengambil peran sangat besar dalam memberikan bukti bahwa lirik lagu rohani Kristen bersumber dari pengalaman real. Ketika membaca kitab Mazmur, pembaca sedang memasuki ruang kudus, tempat dimana Tuhan bertemu pria dan Wanita dengan cara tertentu. Pembaca akan melihat bahwa pertuturan Tuhan dengan umat-Nya ialah secara langsung, hangat, intim, dan jujur. Menurut Tremper Longman Kitab Mazmur merupakan semacam literatur kudus dalam Alkitab. Tempat dimana Tuhan bertemu umat-Nya dengan khusus, di mana umat-Nya berhubungan dengan Dia melalui pujian dan keluhan. Sebagaimana tempat-tempat Kudus dalam Perjanjian Lama, khususnya kemah perhimpunan dan bait Allah yang merupakan pusat kehidupan umat Tuhan, demikian juga posisi kitab Mazmur yang berada di tengah Alkitab. ${ }^{49}$

Pengalaman-pengalaman yang mengilhami lirik lagu nyanyian Rohani Kristen bersifat one and only atau bisa dikatakan unik. Tentu saja hal ini juga berlaku bagi nyanyian sekuler. Berdasarkan konteks yang demikian maka menganti lirik lagu, khusunya lirik lagu sekuler menjadi lirik lagu rohani adalah tidak tepat. Mengubah lirik lagu sekuler menjadi rohani Kristen sama dengan menukar pengalaman setiap orang yang masing-masing unik. Atau dengan kata lain memaksakan pengalaman satu orang kepada pengalaman yang lain. Pemaksaan demikian tidaklah etis dalam perspektif iman Kristen.

\section{Praktek “Mengubah Lirik Lagu” Dalam Kaitan Dengan Misi Kontekstual}

Istilah kontekstualisasi dalam dunia Kristen berkaitan erat dengan misiologi. Secara sederhana hal ini berarti bahwa kontekstualisasi merupakan sarana yang digunakan oleh orang Kristen baik secara personal dan komunal supaya tugas misi dapat dilaksankan dengan efisien dan efektif dimanapun dan kapanpun. Menurut David J. Hesselgrave dan Edward Rommen, dalam dunia Perjanjian Baru praktek-praktek kontekstualisasi terlihat lebih dominan dibandingkan Perjanjian Lama dikarenakan 2 hal penting yaitu: Pertama, kedatangan Kristus dan penggenapan karya penyelamatan-Nya memberikan fokus bagi berita keagamaan. Kedua, dokumen Perjanjian Baru tidaklah pertama-tama bersifat deskriptif. Artinya, dokumendokumen itu tidak saja melaporkan misi jemaat, melainkan justru merupakan alat-alat yang digunakan dalam penyebaran tersebut. ${ }^{50}$

Menurut Stephen B. Bevans sekarang ini teologi haruslah kontekstual oleh karena beberapa aspek yaitu: Ciri inkarnatif agama Kristen. Kasih Allah besar bagi dunia ini (Yoh

${ }^{48}$ L. Thomas Holdcroft, Kitab-Kitab Sejarah (Malang: Gandum Mas, 1992), 65.

49 Tremper Longman III, Bagaimana Menganalisa Kitab Mazmur (Malang: Literatur SAAT, 2007), 8.

${ }^{50}$ David J. Hesselgrave \& Edward Rommen, Kontekstualisasi: Makna, Metode dan Model (Jakarta: BPK GUnung Mulia, 2006), 24.

264 | Copyright@ 2021, CARAKA, ISSN 2722-1407 (Cetak), 2722-1393 (Online) 
3:16) sehingga Ia berkehendak untuk membagikan diri-Nya sendiri kepada manusia, serta mengundang mereka masuk ke dalam relasi yang memberi kehidupan dengan diri-Nya. Ketika Allah hendak melaksanakan hal ini maka sarana-sarana komunikasi harus sedemikian rupa sehingga mahluk manusia dapat sungguh memahami, suatu cara yang mengungkapkan kenyataan tentang apakah sebenarnya undangan untuk masuk ke dalam persahabatan dan relasi dimaksud. Dan demikianlah Allah menjadi manusia (Yoh 1: 14). Selain itu Doktrin inkarnasi memaklumkan bahwa Allah diwahyukan bukan terutama dalam gagasan-gagasan, melainkan dalam realitas nyata. ${ }^{51}$

Realitas yang dikerjakan oleh Allah dalam meyatakan kasihnya kepada dunia melalui inkarnasi dipahami sebagai kontekstualisasi. Oleh karena berita tentang kasih Allah harus kontekstual maka praktek merubah lirik lagu sekuler menjadi lirik lagu rohani Kristen bisa dimaknai dalam bingkai demikian. Pemahaman ini dengan kata lain menunjukan bahwa merubah lirik lagu sekuler menjadi lirik lagu rohani bisa berarti sebagai misi kontekstual untuk memberitakan kasih Allah yang besar bagi semua manusia dimanpun dan kapanpun. Bagi setiap orang yang belum secara rohani terhisap sebagai anggota tubuh Kristus, bisa jadi melalui mendengar lagu sekuler yang lirik lagunya diubah menjadi versi Rohani Kristen bisa mengenal dan mengalami kasih Allah di dalam kehidupan mereka.

\section{Praktek “Mengubah Lirik Lagu” Dalam Kaitan Ibadah Kristen}

Sejarah Kristen menunjukan bahwa Ibadah Kristen tidak bisa dilepaskan dari nyanyian dan musik gereja. Nyanyian dan musik digunakan sejak masa Perjanjian Baru hingga sekarang sebagai sarana untuk memuliakan Allah."52 Bahkan nyanyian jemaat akhirnya menjadi identitas yang melekat pada umat Kristen. Kenneth W. Osbeck memberi pernyataan bahwa iman Kristen adalah iman yang bernyanyi. ${ }^{53} \mathrm{Hal}$ ini berarti bahwa nyanyian jemaat merupakan ekspresi dari imanya. "Nyanyian Jemaat merupakan pencerminan dari vitalitas spiritual suatu jemaat dan menjadi respon atas anugerah yang diberikan Tuhan." ${ }^{54}$ Pentingnya nilai dari pujian Kristen terlihat dari syair berikut ini;

The Power Of Christian Song

There's something about a fine old hymn

hat can stir the heart of a man:

That can reach to the goal of his inmost soul

Such as no mere preaching can

It,s more than the tune of the song he sings

And is's more than the poet's rhyme-

${ }^{51}$ Stephen B. Bevans, Model-Model Teologi Kontekstual (Maumere - Flores: Penerbit Ledalero STFK Ledalero, 2002), 18 .

${ }^{52} \mathrm{Https} / / /$ docplayer.info/46988253-Bab-2-nyanyian-dan-musik-gerejawi-dalam-ibadah-kristen.html, diakses tanggal 17 jam 12.00 .

${ }^{53}$ Kenneth W. Osbeck, 101 Hymns Stories, (Michigan: Kregel Publications, 1982), xi.

${ }^{54}$ Listya, Nyanyian Jemaat dan Perkembangannya, (Salatiga: Fakultas Teologi UKSW, 1999), 
It's the Spirit of God working thorough these things

That gives them their power sublime

So we thank Thee, Lord, for the fine old hymns

May we use them again and again

As we seek to save from a hopeless grave

The souls of our fellow men. ${ }^{55}$

Berdasarkan hal inilah maka Florovsky sebagaimana dikutip oleh James F. White menyatakan bahwa "ibadah Kristen utamanya dan secara esensial, adalah kegiatan puji-pujian dan penyembahan, yang juga mengimpliksaikan pengakuan penuh syukur atas Kasih Allah yang merangkul kita dan kebaikan Kasih-Nya yang menebus kita." ${ }^{56}$ Rasul Paulus dalam Efesus 5: 18-19 dengan tegas memerintah kapada jemaat "janganlah mabuk oleh anggur karena menimbulkan hawa nafsu, tetapi hendaklah kamu penuh dengan Roh, dan berkatakatalah seorang kepada yang lain dalam Mazmur, kidung puji-pujian dan nyanyian rohani. Bernyanyi dan bersoraklah bagi Tuhan dengan segenap hati.” Berdasarkan nasehat rasul Paulus maka dalam ibadah lebih baik menyanyinkan mazmur, kidung pujia-pujian dan nyanyian rohani.

Menurut Riemer salah satu dasar beribadah adalah kerinduan untuk memandang Tuhan. Memandang bukan dengan mata kepala, melainkan melihat dengan mata hati yang beriman. Memandang secara rohani: melalui pendengaran timbulah kepercayaan yang begitu kuat dalam hati manusia sehingga dapat berseru "aku melihat kemuliaan Tuhan." 57 Oleh karena fokus dalam ibadah Kristen salah satunya adalah puji-pujian dan penyembahan, yang juga mengimpliksaikan pengakuan penuh syukur atas kasih Allah yang merangkul kita dan kebaikan Kasih-Nya yang menebus kita, maka adalah tidak tepat jika dalam ibadah dinyanyikan lagu-lagu sekuler yang liriknya telah diubah menjadi lirik lagu rohani. Memang lirik lagunya rohani namun dalam ibadah Kristen kenyataan tersebut dapat merusak penghayatan jemaat untuk secara total menghargai kasih Allah dan memandang kemuliaanNya.

\section{KESIMPULAN}

Praktek mengubah lirik lagu dalam nyanyian sekuler menjadi nyanyian rohani boleh dilakukan apalagi jika hal tersebut memiliki tujuan untuk mewartakan kasih Allah kepada dunia. Meskipun demikian ada pertimbangan sebagai berikut ini: Pertama, adalah lebih baik jika pihak-pihak baik secara pribadi atau kelompok meminta izin terlebih dahulu kepada pemiliki hak cipta jika hasil karyanya akan dimodifikasi. Kedua, nyanyian sekuler yang lirik

\footnotetext{
${ }^{55}$ Kenneth W. Osbeck,

${ }^{56}$ James F. White, Pengantar Ibadah Kristen (Jakarta: BPK Gunung Mulia, 2017),10.

${ }^{57}$ G Riemer, Cermin Injil: Ilmu Liturgi (Jakarta: Yayasan Komunikasi Bina Kasih/OMF, 1995),41.
} 
lagunya diubah menjadi lirik lagu rohani lebih baik tidak dinyanyikan di dalam gereja apalagi dalam nyanyian ibadah.

\section{REKOMENDASI}

Hasil penelitian ini diharapkan memberikan wawasan dan dasar yang komperhensif bagi Gereja dalam menyikapi fenomena mengubah lirik lagu sekuler menjadi rohani dengan pertimbangan etis Kristen yang dapat dipertanggunjawabkan. Penelitian ini dapat dikembangkan misalnya untuk mendapatkan alasan gereja yang mengubah lirik lagu sekuler menjadi rohani Kristen dan menyanyikanya dalam gereja.

\section{DAFTAR PUSTAKA}

Bevans, Stephen B. Model-Model Teologi Kontekstual (Maumere - Flores: Penerbit Ledalero STFK Ledalero, 2002).

Bertens, K. Etika (Jakarta: Gramedia Jakarta, 1993)

Darmaputera, Phil. Eka Etika Sederhana Untuk Semua: Perkenalan Pertama ( Jakarta: BPK Gunung Mulia, 2002).

Geisler, Norman L. Etika Kristen: Pilihan dan Isu (Malang: Seminari Alkitab Asia Tenggara, 2000)

Hesselgrave, David J. \& Rommen, Edward Kontekstualisasi: Makna, Metode dan Model (Jakarta: BPK GUnung Mulia, 2006).

Hibbert, Mike Viv Pelayanan Musi (Yogyakarta: Yayasan Andi 1988)

Holdcroft, L. Thomas Kitab-Kitab Sejarah (Malang: Gandum Mas, 1992).

Kraeuter, Tom Kunci Keberhasilan Pemimpin Pujian dan Musik (Bandung: Lembaga Literatur Baptis 2001).

Listya, Nyanyian Jemaat dan Perkembangannya, (Salatiga: Fakultas Teologi UKSW

Longman III, Tremper Bagaimana Menganalisa Kitab Mazmur (Malang: Literatur SAAT, 2007).

McNeill, Rhoderick J. Sejarah Musik 1 (Jakarta: BPK Gunung Mulia, 1998)

McNeill, Rhoderick J. Sejarah Musik 2 (Jakarta: BPK Gunung Mulia, 1998)

Osbeck, Kenneth W. 101 Hymns Stories, (Michigan: Kregel Publications, 1982).

Riemer, G. Cermin Injil: Ilmu Liturgi (Jakarta: Yayasan Komunikasih Bina Kasih/OMF, 1995)

Sasongko, Nindyo. Mengenal Nyanyian Gereja Dan Tempatnya Dalam Liturgi (jurnal Veritas 8/2 Oktober 2007), 205-229.

Schnittjer, Gary Edward The Torah Story: An Apprenticeship On The Pentateuch (Malang: Gandum Mas, 2015).

Siahaan, Rohani. Memuji Dengan Nyanyian Dalam Ibadah Jemaat. (Jurnal Jafray Sekolah Tinggi Theologia Jaffray vol.5, nol. 2007)

Smith, Jane Stuart dan Carlson, Betty Karunia Musik: Para Komponis Besar dan Pengaruh Mereka (Surabaya: Momentum, 2003)

Sudarsono, Andreas dan Widjana, Dorean Kisah Nyata di Balik Lagu Pilihan (Bandung: Lembaga Literatur Baptis, 2005).

Suhendar, Deris Aspek Hukum Perubahan Bahasa Terhadap Lirik Lagu Tanpa Izin Berdasarkan Undang-Undang Nomor 19 Tahun 2002 Tentang Hak Cipta (Bandung: Universitas Padjajaran Bandung 2014)

Suseno, Frans Magnis Etika Dasar: Masalah-Masalah Pokok Filsafat Moral (Yogyakarta: Penerbi Kanisius, 1987).

White, James F. Pengantar Ibadah Kristen (Jakarta: BPK Gunung Mulia, 2002) 
Https://docplayer.info/46988253-Bab-2-nyanyian-dan-musik-gerejawi-dalam-ibadahkristen.html

Https://andabertanyaateismenjawab.wordpress.com/2013/08/01/apa-sebenarnya-sekuler-itu-2/. Https://www.youtube.com/watch?v=ThM0EdT1ByU Https://www.youtube.com/watch?v=Z-UvDURdems Https://www.youtube.com/watch?v=OP6mejYF4Tg Https://www.youtube.com/watch?v=HjlztOvV5AM Https://www.youtube.com/watch?v=6ZFdbaU8JPw Https://www.youtube.com/watch?v=H0uI7dKCYYs Https://www.youtube.com/watch?v=1ak17RxcqBQ Https://www.youtube.com/watch?v=FVBYF0ae3wg Https://www.youtube.com/watch?v=Zhpx5qqMIVc Https://www.youtube.com/watch?v=kSnnr1I9M_U Https://www.youtube.com/watch?v=Tet6_B1StEM Https://www.youtube.com/watch?v=NPnVTF5blMg Https://www.youtube.com/watch?v=7xLR7r_0Ktc Https://www.youtube.com/watch?v=FsDX5QmO9rc Https://www.tabloidbintang.com/lirik-lagu/read/795/lirik-lagu-selow-via-vallen. Http://forumkristen.com/index.php?topic=54775.0. Http://one-olyvia.blogspot.com/2012/01/apa-itu-cover-song.html. Https://batam.tribunnews.com/2018/01/25/cover-lagi-artis-nggak-boleh-asal-lho-cek aturannya-yuk.

Https://www.facebook.com/notes/rasyadan-alghazian-grantiarno/mudah2an-ini-bisamembantu-menjelaskan-perbedaan-cover-dengan-plagiat-/396712254829/

Https://any.web.id/arti-cover-song.info

Http://one-olyvia.blogspot.com/2012/01/apa-itu-cover-song.html Https://jabar.tribunnews.com/2017/04/12/.

Https://www.cnnindonesia.com/hiburan/20190115105759-227-360889/kasus-jogja-istimewapro-prabowo-bisa-dibawa-ke-ranah-hukum.

Https://www.gurupendidikan.co.id/8-pengertian-lirik-lagu-menurut-para-ahli-lengkap/ Https://www.hukumonline.com/klinik/detail/ulasan/lt5c8f438ae674d/hukumnyamemodifikasi-lirik-lagu-untuk-kampanye-pemilu.

Http://terangalkitab.net/2015/06/15/nyanyian-pujian-hana/. ${ }^{1}$ Http://forumkristen.com/index.php?topic=54775.0. 